\title{
Working conditions of a nursing team in mental health facility
}

\author{
Condições de trabalho da equipe de enfermagem em dispositivo de saúde mental \\ Condiciones de trabajo del equipo de enfermería en dispositivo de salud mental
}

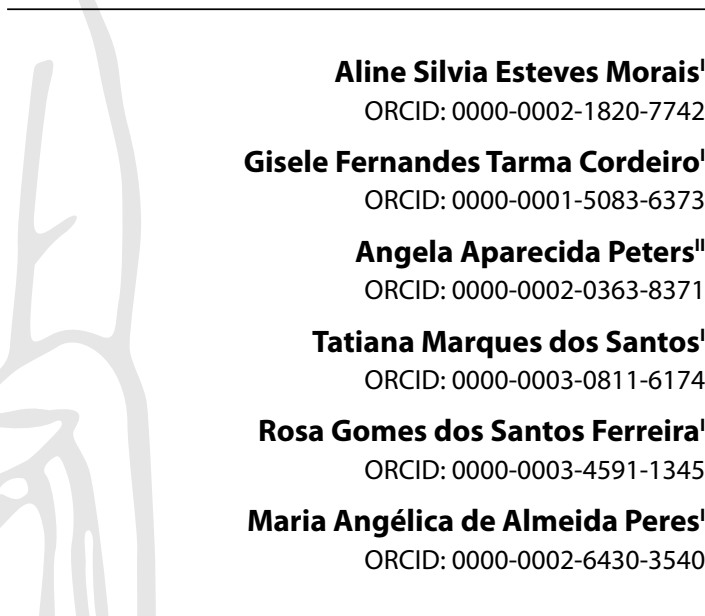

'Universidade Federal do Rio de Janeiro. Rio de Janeiro, Rio de Janeiro, Brazil.

"Faculdade de Ciências Médicas e da Saúde de Juiz de Fora. Juiz de Fora, Minas Gerais, Brazil.

How to cite this article: Morais ASE, Cordeiro GFT, Peters AA, Santos TM, Ferreira RGS, Peres MAA. Working conditions of a nursing team in mental health facility. Rev Bras Enferm. 2021;74(Suppl 3):e20200407. https://doi.org/10.1590/0034-7167-2020-0407

Corresponding author:

Gisele Fernandes Tarma Cordeiro E-mail: gisele_fernandes123@hotmail.com

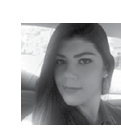

EDITOR IN CHIEF: Dulce Barbosa ASSOCIATE EDITOR: Alexandre Balsanelli

Submission: 07-03-2020

Approval: 11-01-2020

\begin{abstract}
Objective: To analyze how the nursing team from a Psychosocial Care Center II relates its insertion in the service with the work process. Methods: Descriptive, analytical research outlined as a case study with a qualitative approach. The data were collected through semi-structured interviews with nursing professionals and went through content analysis subsidized by Bardin's work. Results: Two thematic categories emerged: a) Ways of intake in the nursing services at the Psychosocial Care Center; b) Setbacks in nursing routine at the Psychosocial Care Center. Final considerations: The fact that the professionals have not planned to work in mental health nor have training impacts the rhythm of psychosocial care development at the Psychosocial Care Center, forcing them to seek training in the field after admission. Unmotivated by the working conditions, the nursing team suffers from the absence of an interdisciplinary partnership and goes to great lengths to approach psychosocial care. Descriptors: Psychiatric Nursing; Mental Health; Nursing Team; Mental Health Services; Working Conditions.
\end{abstract}

\section{RESUMO}

Objetivo: Analisar como a equipe de enfermagem de um Centro de Atenção Psicossocial II relaciona sua inserção no serviço com o processo de trabalho. Métodos: Pesquisa descritiva, analítica, delineada como estudo de caso, com abordagem qualitativa. Os dados foram coletados por entrevista semiestruturada com profissionais de enfermagem e passaram pela análise de conteúdo subsidiada pela obra de Bardin. Resultados: Emergiram duas categorias temáticas: a) Formas de ingresso no serviço de enfermagem do Centro de Atenção Psicossocial; b) Contratempos no cotidiano da enfermagem em Centro de Atenção Psicossocial. Considerações finais: $O$ fato de os profissionais não terem planejado atuar na saúde mental nem disporem de preparação impacta consideravelmente o ritmo do desenvolvimento do cuidado psicossocial no Centro de Atenção Psicossocial, forçando-os a buscar capacitação na área após admissão. Desmotivada pelas condições de trabalho, a equipe de enfermagem sofre pela ausência de parceria interdisciplinar e desdobra-se para aproximar-se do cuidado psicossocial.

Descritores: Enfermagem Psiquiátrica; Saúde Mental; Equipe de Enfermagem; Serviços de Saúde Mental; Condições de Trabalho.

\section{RESUMEN}

Objetivo: Analizar como equipo de enfermería de un Centro de Atención Psicosocial II relaciona su inserción en el servicio con el proceso de trabajo. Métodos: Investigación descriptiva, analítica, delineada como estudio de caso, con abordaje cualitativo. Datos recogidos por entrevista semiestructurada con profesionales de enfermería y pasaron por análisis de contenido subsidiada en Bardin. Resultados: Emergieron dos categorías temáticas: a) Formas de ingreso en el servicio de enfermería del Centro de Atención Psicosocial; b) Contratiempos en el cotidiano de la enfermería en Centro de Atención Psicosocial. Consideraciones finales: El hecho de los profesionales no tener planeado actuar en salud mental ni disponer de preparación, impacta considerablemente el ritmo del desarrollo del cuidado psicosocial en Centro de Atención Psicosocial, forzándolos a buscar capacitación en el área después admisión. Desmotivada por condiciones de trabajo, el equipo de enfermería sufre por la ausencia de colaboración interdisciplinar y redoblarse para aproximarse del cuidado psicosocial.

Descriptores: Enfermería Psiquiátrica; Salud Mental; Equipo de Enfermería; Servicios de Salud Mental; Condiciones de Trabajo. 


\section{INTRODUCTION}

Mental health care, currently supported by legislation that supports community-based treatment services and understood as a complex social process, is supported by a network of substitute services that replace the psychiatric hospital to increase the spaces to care for users' in psychological suffering. As an obstacle to this change, there are issues such as the dissociation of mental health treatment from other health care professionals and professionals' belief that only specialists can take care of users in this field ${ }^{(1-2)}$.

The measures taken in the health scenario in Brazil counted on the scope of articulation between mental health services in the Unified Health System (SUS) in line with the Mental Health Policy (MHP) and the Psychosocial Care Network (RAPS), which brought the ramification in the political field about the integration between territorial community facilities, through the ministerial order MS/GM No. 3.088/2011. In this scenario, it was possible to create, expand and articulate health care attention points for people in psychological pain and need resulting from crack use, alcohol, and other drugs, through services: Psychosocial Care Centers (CAPS), Coexistence Centers, Urgency services and Psychiatric Emergency Services in General Emergency Room, Psychiatric Wards in General Hospitals, Community Centers and Schools ${ }^{(3)}$.

As far as CAPS is concerned, it is a community co-operation to assist individuals with severe and persistent mental illness. Regarding its operation, is considered an articulation service in the territories and among RAPS, presented in modalities defined by increasing order of size/complexity and population coverage $(\mathrm{I}, \mathrm{II}, \mathrm{III})$ and the public which will help: adults (CAPS), alcohol and other drugs users (CAPS ad), children and adolescents (CAPS i) and the CAPS that provides 24 hours care (CAPS III) ${ }^{(4)}$.

In this regard, the health team, especially the nursing team, takes on a new role at CAPS with hospital care since the service structure aims to maintain the psychosocial paradigm of mental health care. In this paradigm, health professionals have a community-based structure to establish psychosocial relations, which encompass a variety of therapeutic activities for users (including family members), focused on the individuality of each subject, according to the Singular Therapeutic Project (STP) ${ }^{(5)}$.

The STP is planned as an assistive technology that should be built and used by the professionals from the CAPS interdisciplinary team as an instrument for psychosocial care, whose purpose is to meet the principle of integrality, which envisions people's needs in the territory, encompassing the biopsychosocial aspects. In its content, the STP is an integrated care plan and works as an organization strategy for the service provided, aligned with the humanization and continuity of care in the expanded clinic, which aims to seek the users'autonomy ${ }^{(5)}$. Although clearly defined, the STP constitutes a complex care technology, which requires the professional's high potential for mental health care and interdisciplinarity.

It is worth mentioning that, for the development of the work process, the CAPS nursing team faces setbacks of different natures to guarantee quality assistance. According to each one's experience and background, feelings such as fear and insecurity can manifest in relationships with the users of mental health services, caused by prejudice and stigma, still permeated in society, which perceived them as an "aggressive population." This situation exists as a remnant of hundreds of years of an asylum discourse immersed in distorted perceptions that guaranteed social life exclusion, considering isolation as a therapeutic resource ${ }^{(6)}$.

This socio-historical condition inherent to psychiatry and associated with the complexity of practices and constituent processes of those services culminate in persistent challenges about the specific assistance that should support the nursing care in mental health to contribute to the maintenance of people in psychological pain in the Primary Health Care services. However, it is common to refer them to CAPS, even when the case is not classifiable as medium or high risk, levels that, as recommended, justify the procedure. This situation overloads CAPS while keeping people away from the Family Health Strategy (ESF) follow-up, which should be CAPS' leading partner service.

However, before discussing a problem at the ESF, it is necessary to unveil CAPS professionals' work process and reflect on it since there are strong indications that intersectorality has not been sustained due to the lack of dialogue among teams. Therefore, the study's scientific relevance subsidizes the discussions related to the work process of CAPS nursing professionals, enabling the understanding of the aspects that involve psychosocial care in this facility.

\section{OBJECTIVE}

To analyze how the nursing team from a Psychosocial Care Center II relates its insertion to the work process.

\section{METHODS}

\section{Ethical Aspects}

The Research Ethics Committee approved the research reported in this article of the Anna Nery School of Nursing/ São Francisco de Assis Health Care Institute, Federal University of Rio de Janeiro, under the Consubstantiated Opinion, in compliance with/ in attendance to the recommendations for research involving human beings regulated by Resolution 466/12 of the National Health Council. The information was made available voluntarily by the participants in agreement with the study by signing the Free and Informed Consent Form.

\section{Theoretical-methodological framework}

The theoretical referential used to support the research was the norms that conduct mental health care in Brazil since the Psychiatric Reform (Law 10.216/01), and the scientific literature available on the subject emphasized psychosocial rehabilitation $^{(1,2)}$. This referential option explored a scientific background in the most recent literature about the investigation problem's context. It is possible to discuss how this concept has supported the development of CAPS nursing teamwork regarding nursing care and psychosocial rehabilitation ${ }^{(7-8)}$.

\section{Type of study}

It is descriptive, analytical research, designed as a case study, with a qualitative approach ${ }^{(9)}$. The "case study" research strategy investigates a current phenomenon based on a given real-life 
context, especially when the limitations between the phenomenon and the context are undefined. In this sense, it intends, through detailed information, to understand a specific situation, which was identified as a concrete issue to be analyzed. We intend to see how the CAPS nursing team under survey relates its insertion in the service following their work process.

The data treatment followed the content analysis technique, which allows exploring the research data with methodological rigor to emerge the most descriptive themes to be analyzed ${ }^{(9-10)}$.

\section{Study Scenario}

A CAPS II located in a region of Rio de Janeiro known for the high number of impoverished communities and urban violence, factors that directly influence the nursing team's work process, was chosen as the research scenario. Due to its classification, this CAPS operates from Monday to Friday, from 9 am to $5 \mathrm{pm}$, with services provided by an interdisciplinary team composed of nurses, nursing technicians, and nursing assistants, psychiatrists, psychologists, occupational therapist, music therapist, pharmacist, and artisans, besides the administrative staff.

\section{Data source}

The research participants from the nursing team met the proposed inclusion criteria: work as a nurse, nursing assistant, or nursing technician at CAPS for more than six months. The study excluded professionals who were on sick leave or vacation during the data collection period. From the total of eight professionals that met the inclusion criteria, one nurse, three nursing technicians, and two nursing assistants accepted to participate in the survey.

\section{Data collection and organization}

Between January and February 2019, data collection took place through semi-structured interviews, which were audio-recorded and fully transcribed shortly after its completion. The interviews took place according to each participant's availability, in reserved environments, outside their workplaces, at a convenient time, lasting between 30 and 90 minutes, following guiding questions about the work process of the nursing team at CAPS. To identify participants, researchers took the first letter of the profession and the sequential number according to the interviews' order to ensure the anonymity of information.

\section{Data analysis}

The data went through the content analysis subsidized by the work of Bardin ${ }^{(11)}$, consisting of three chronological poles, presented in three stages: a) Pre-analysis - First, organization and recognition of the interview data was elaborated through quickly readings of the transcriptions, which allowed, after several readings, to organize the material according to its representativeness, homogeneity, and pertinence, so that the data obtained could be thoroughly explored, aiming to answer the theoretical questions posed and thus corroborating the interpretation; b) Exploration of the material - The data were classified and aggregated, taking into account the focus on the nursing team itself, which allowed data codification and identification of the nuclei of meaning, following the objectives; $c$ ) Treatment and interpretation of the results obtained by articulating the themes found with the body of scientific knowledge that constitutes the theoretical framework of the research.

\section{RESULTS}

With the contents' analysis, two thematic categories appeared: a) Ways of entering the Psychosocial Care Center; b) Setbacks in the nursing routine in a Psychosocial Care Center.

\section{Ways of intake in the nursing services of the Psychosocial Care Center}

The research participants were two men and four women in the age group between 38 and 66 years old, one undergraduate nursing professional and five with mid-level degree, with training time varying from 20 to 31 years. As for the complementary training of these professionals, a nursing technician had a mid-level specialization in mental health, a nursing assistant had training and qualification course in mental health, and the nurse had a master's degree in mental health.

The results of this research highlighted the way professionals reported their intake into CAPS II service:

It was at random. We had to check the closest places [to the residence] [...] / asked: "What is CAPS? He answered: "Psychosocial Care Center." And I said: "You haven't told me anything so far." (T1)

I fell into this job. I was working in the Intensive Care Center as a civil servant, I was stationed in a federal unit. When this unit was handed back to the union administration, all employees were relocated, and I went to CAPS, not knowing that it was a mental health unit. (T2)

I readapted [...] / was working in the maternity ward, then I went to work in public health, in the health center and then I had to adapt to work in a place closer to my residence, which was here. (T3)

Regarding training to meet the demand for mental health at CAPS, the professionals reported the lack of knowledge and guidance when they started working on mental health, with the specific learning taking place during the experience:

We learned on a daily basis, with effort and determination. We had no time to eat, no time for anything, [...] / went to the director and told her that I started the work without any guidance about psychology, for example [...] I'm here to "make it work" [...] as for medication, I was interested in learning, I never worked with controlled medication. We worked with medical clinic drugs. (T1)

It is the experience. We read some texts [...] something very specific [...] there are the discussions of clinical cases, the supervision. (T2)

There was an introduction, a training course at Fiocruz; an introduction to psychology, but what guides me is when we make use of nursing practice, the nursing training [...] we have that guideline on how to approach that user [...]. (T3) 
I taught mental health, I studied disciplines of the master's degree, which were directed to the mental health field. My dissertation defense was in this field. (N1)

The lack of mental health training is a factor that increases setbacks in mental health care practice offered by nursing professionals. Participants reported that those difficulties stem from superficial knowledge about how to provide care for people in mental pain and how to work in mental health facilities, with specific care technologies different from those offered in other care environments:

Not knowing the technical terms, nor how to deal with reception, attention to patients [...] not knowing anything about mental health. (A1)

The difficulties are countless. The infrastructure, the place to take care for [patients], [...] there are much more obstacles than solutions [...] I was very worried because I was not familiar with mental health care. (A2)

It is difficult to adapt when you are not prepared to work in mental health. You need to get rid of some concepts [...] you need flexibility to work in mental health, malleability, differentiated attention. [...] you leave a process based on techniques, like intensive therapy, to something less tangible, which is mental health... it's hard. (T2)

\section{Setbacks in daily nursing at the Psychosocial Care Center}

Feelings of fear and anguish reported by nursing professionals, resulting from the work process at CAPS, bring visibility to factors that influence the job at this facility, such as organizing the duties, interpersonal relationship of health team professionals, as well as the stigma linked to mental illness:

You have no difficulty with the patient, with the policy, [...] it's a problem with the team, an issue among people [...] anything that you can take as personal, because any criticism, any question you address, everything you say [...] can hurt the vanity of others. (N1)

[...] The meeting was tense and even "frightening". I started to protect myself with crossword puzzle, naps. It was a place of terror. Doctor knocking on the door, a mess [...] mental health is so great, but it seems that the employees have more disorders than the patients. (T1)

[...] I was far from my reality [...] I always had a certain distance from mental health [...] in the beginning it was a little scary. (T3)

Before someone told me "you will work with a user with mental illness", I was afraid of those things, I was afraid. I saw human beings with a mental disorder, I thought that at any moment they would assault me, they would scream. I had this impression but today I have another. (A1)

I was horrified by CAPS [...] I thought that here the work didn't pan out, because of neglect [...] it wasn't something I liked, because maybe I was too organicist [...] and not on the issue of the psychological, mental illness [...]. (N1)

The crisis is getting worse, the time of crisis is diminishing, the system is not supporting [...] it will go back to what it was before [insane asylum], in disguise, but it will. So, I think that deep down it is already coming back. (T2)

Issues inherent to deficiencies in the mental health system and the insufficiency concerning the application of public policies in the field were also pointed out as generating difficulties for the nursing team to carry out their work at CAPS:

There is no structure, you get into a work overload that is sickening. It's sickening that you can't be with that user [...] to see your colleague distressed because you can't follow the case, due to policy issues. (A1)

It is necessary to accompany the user in the territory, and you do not have funding for the travel, [...] you pay for it. You have hired staff coming to work without money. These are sickening issues; you work in a mental health facility to take care of the mental health of others by harming your own mental health. The stakes are too high. (T2)

It has no structure, here [...] the resource is not enough, there is a lot of red tape. (T1)

In mental health, we live a delicate moment. Today more than when I started, 10 years ago [...] there is a wrecking of health facilities, of tools for you to treat users, wrecking of human resources. (T3)

\section{DISCUSSION}

Most professionals participating in this research did not want to work in mental health and arrived at CAPS due to unplanned situations. Once inserted into the CAPS service under research, these professionals faced interpersonal relationships characterized by hierarchies, little dialogue, and distance from peers, resulting in difficulties in understanding the nursing duties.

During the CAPS adaptation phase, the way of nursing professionals' insertion interfered in the work, which, at first, did not have the theoretical-practical direction of psychosocial rehabilitation by the nursing team, which requires investment in activities that lead to the expansion of socialization, level of contractuality, self-care, among others ${ }^{(12)}$. The inexperience of working in the field, because the professionals did not get a practice-oriented reception or training, weighed in the answer of the majority of the participants, who did not want to be in a mental health service because they did not feel qualified to care for people in psychological pain, which generated professional dissatisfaction, fear, and anguish.

It is important to delineate the form of insertion of the nursing professional at CAPS since it impacts the service performance and the professionals' mental health, verified by tensions and insecurities related to adaptation in the new work environment. Several factors contribute to nursing professionals'vulnerabilities while coping daily with the service: long working hours, reduced staff, interprofessional relations, and care for themselves. When we add a lack of training to the presented scenario, the work process becomes exhausting, resulting in interferences in the quality of care and the employee's life ${ }^{(13,15)}$

The lack of knowledge about controlled medications, signs and symptoms of mental illness, technical terms used in the field, 
and also the stereotyped views about the person in psychological distress lead to centralize the nursing care on medication and to deal with the user's behavior more in a protective than therapeutic way $^{(14)}$. In the case of the CAPS studied, that happened but was transformed. The nursing team understands that the model to be developed at CAPS was different from what they historically knew or had learned.

The mental health service is not the primary choice for most nursing professionals, whether they are undergraduate or have a certificate degree. Historically, mental health is not an attractive field for nursing professionals, which has not yet been modified by the new mental health policies. This research showed that the intake into CAPS had motivations different from the inclination towards the field, such as proximity to the professional's residence and the need for service transfer, which directly affects the nursing work and its progress, requiring more time for the professional to reach some domain in the specialty ${ }^{(16)}$.

It is interesting to realize that those nursing professionals, despite reporting their mental health field issues related to what they felt as stigma and prejudice, nowadays defend the psychosocial model. Thus, we can see that the nursing team can adapt to the community care new facilities, assuming a professional identity compatible with this space for care. For this, they need working conditions favorable to perform.

For psychosocial care, the nursing team must abide by the reformist precepts, which requires knowledge about mental health policies. When introduced in CAPS unwilling to work in that scenario and without immediate training, nursing professionals face setbacks of different natures, which are the consequence of the lack of knowledge about indispensable technologies in the process of mental health work in the territory, such as the Singular Therapeutic Project (STP) ${ }^{(15)}$. The absence of nursing training and continuing education to work in assistance facilities focused on psychosocial rehabilitation makes it difficult to immediately follow their role within CAPS and delays investment in interdisciplinary articulation to plan and execute interventions centralized on the health needs of each user in their community ${ }^{(17)}$.

Thus, this research highlights the importance of previous reception and training of nursing professionals who will work at CAPS and continuing education ${ }^{(17)}$. In a study on continuing education, the authors point out this as a tool for improving services and conceived as a profitable investment in terms of work processes ${ }^{(14)}$. In mental health, this strategy is necessary for nursing. Those professionals are in a more significant number (nurse and nursing technician) and occupy an important position in the CAPS articulation with other community services when treating psychosocial rehabilitation. The relationship between continuing education and psychosocial rehabilitation are in line with the development of SUS and psychiatric reform ${ }^{(7-15,17-18)}$.

As to the balanced development of the nursing work process at CAPS, there is a certain distance from the team and local administration, a fact that demonstrates little dialogue between those involved with the service at different levels of performance. In this respect, it is worth reflecting on the fact that technical actions and of biologicist nature, bringing the scenario of psychosocial care closer to the hospital environment, distance care from the proposition that replaces the previous asylum paradigm, fostering possibilities for exclusive, stigmatizing, punitive and coercive practices, which can be used when there is no nursing care methodology for severe cases of mental disorders ${ }^{(7)}$.

Professionals without proper theoretical-practical training in the mental health field can reproduce practices that are no longer used and cause setbacks in the assistance field instead of advancing psychosocial strategies. Therefore, it is necessary to discuss Psychiatric Reform and its ramifications to strengthen the foundations that support psychosocial care in this field and the scenarios of health practices ${ }^{(2)}$.

Nursing professionals revealed that they carried the imaginary that people with mental disorders were aggressive and dangerous. This prejudice, still very present in society, brings suffering and fear in helping this population, hindering the connection and empathy, interfering directly in the therapeutic communication, one of the powerful instruments of assistance for the nursing team in these services ${ }^{(19)}$.

In studies, it is observed that nursing professionals lead the list of mental health professionals who are victims of aggression when compared to other health categories. Among them, nursing technicians are the most exposed due to the more significant time they spend in proximity to the users, which contributes to the development of fear and insecurity to act in this field ${ }^{(20-21)}$.

We must bring as reflection and careful criticism that nursing care in mental health is not inevitably linked to violence, but to empathy, therapeutic listening, and careful observation of users' responses to therapeutic management during direct activities with the patient when in consultation or a therapeutic group. However, this requires a concern with the health of these professionals since severe mental disorders can lead to aggressive responses from users towards health service professionals, which in general is circumvented by teamwork through individualized and specialized care.

CAPS Nursing works very closely with the users because it is also responsible for administering medications, collecting material for exams, checking vital signs, hygiene, and other activities that people in psychological pain tend to refuse, depending on their clinical condition. Therefore, any nursing care action can be violently refused by the users while feeling invaded in their privacy or what they believe is better for them, placing this team in front of more work risks. In this case, nursing professionals do not get entirely rid of that concern, although it does not impede their continuous investment in psychosocial care.

Based on the above, therapeutic listening as a care tool in the context of mental health is a technology that, when well used, reaffirms effective communication between the nursing professional and the person in psychological pain, becoming a fundamental component in the understanding of the subjectivity of the other and establishes the well-founded communication between those involved, prioritizing the quality of care ${ }^{(22-23)}$.

In the CAPS under study, there is professional dissatisfaction in the nursing category, as the reports reveal an indicator of the limit-situation at work that can potentiate work suffering, favoring the development, by professionals, of anxiety, fear, guilt, sleep disorders, burnout, poor self-perceived health or dissatisfaction with work and development of stress, aspects that cause reduction of satisfaction with life ${ }^{(24)}$. 
The precariousness that nursing professionals experience at CAPS is still aggravated by their location in an area of violence, which they did not mention, suggesting that they incorporated this problem into their daily life. Thus, as mentioned before, the nursing professionals moral suffering is experienced routinely, thanks to the dual perception of what is correct to do and the ways hindering this practice, making it impossible to deliver adequate assistance, either due to staff failure, mistaken judgment, or circumstances beyond the control of each professional. Often, those teams encounter ethical and moral dilemmas, which are reflected in decision making as well as in the dynamics and coexistence among peers ${ }^{(25)}$.

Regarding the nursing professionals' training, mental health teaching faces difficulties related to changing the assistance rationality. We have a scenario in which an essential part of the professionals working will probably not be receptive, for example, to students and teachers delivering teaching practices at CAPS because they feel exposed or overloaded. This issue reflects the lack of assistance planning with robust theoretical foundations that support psychosocial care ${ }^{(26-27)}$.

It is worth highlighting studies pointing out the absence of legislation that guarantees the experience of undergraduates in model services when taking the discipline of mental health and psychiatry in Nursing courses, which corroborates the little value given to the discipline and makes it difficult to provide a critical reflexive training regarding the necessary assistance and subjectivity of each individual in their social context $\mathrm{t}^{(27-28)}$.

Another factor indicated by the participants focuses on physical structures: the unavailability of resources to obtain suitable materials for the development of assistance, such as therapeutic workshops. The precarious scenario reflects the lack of investment in public policies, mainly when we talk about the National Mental Health Policy, which has a public without voice and protagonism. Working in this sector, then, becomes frustrating given the neglect of public authorities.

When we analyze SUS's investment in the different regions of the country, the scarcity of resources, both material and human, is repeated. This scarcity makes workers have feelings of powerlessness and frustration for not developing the work they would like. Within this context, the changes approved by Resolution No. 32/2017 "seem contradictory, with a strong tendency to reinforce asylum care, through the expansion of points of care that deal directly with contents such as care specialization and psychiatric hospitals."(13).

In that respect, the change does not occur momentarily but in a continuous process. It should seek training to dissolve this ambiguity generated in the perception of nursing professionals inserted in people's care process in psychological pain. Consequently, is being developed the awareness that CAPS is a RAPS facility directed to care with high psychosocial and transforming potential, for its capacity to accomplish an assistance work articulated with SUS and planned by users, family members, and health professionals ${ }^{(29)}$.

Finally, the professionals still bring to the discussion the difficulty of interdisciplinary teamwork, marked by divergences of ideas and positions, generating a hostile environment of confrontation and interpersonal conflicts. Once again, the CAPS nursing professionals under study do not experience an isolated situation, so it is essential to open space for dialogue between
CAPS team professionals, the administration, and users to find ways to carry out an interdisciplinary articulated work.

When citing special and integral care, nursing professionals show that they are open to multiple perspectives on CAPS care and are concerned with its quality. This point about communication among team professionals in workspaces becomes complex at CAPS. That is a community-based service and depends on the interdisciplinary and intersectoral perspective to reinforce the psychosocial model of mental health care ${ }^{(12)}$.

\section{Study Limitations}

The limitation is that part of the nursing team did not participate in the research. Despite the leading researcher's efforts, some of those professionals were not willing to participate because they were feeling overwhelmed.

\section{Contributions to the fields of Nursing, Health or Public Policy}

This study's contribution is the discussion points that indicate a crisis in mental health care provided by the nursing team inserted at CAPS. When analyzing the daily setbacks that directly affect the work process and those workers' health, we invite to reflect on the continuity of the struggle for providing quality services for mental health users and workers' quality of life.

It is worth remembering that the Psychiatric Reform is procedural, not only a theoretical framework supported by legislation and punctually executed. It must also mainly be the consequence of professionals' training in the field, instrumentalized theoretically to develop their practices. Difficulties, successes, and mistakes are expected as a result of the arduous paradigmatic transformation process, historically and negatively rooted in the social context.

\section{FINAL CONSIDERATIONS}

The result of the research made it possible to identify that CAPS II, here transformed into a research space, has a nursing team that, in its majority, did not choose to work in mental health. The acquisition for conditions to provide care in the field happened after joining the service through practical experience and training or postgraduate courses carried out by individual initiative or the institution.

The reality pointed out in this study shows us a nursing team that still needs to empower itself qualitatively about the assistance provided in mental health services. These are the following factors cited as hindering nursing care at CAPS: lack of training before arriving at the institution, gaps in undergraduate and mid-level professional nursing education, difficult interprofessional relations, precarious infrastructure, and material and human resources, among others that directly affect the care developed by this team.

However, nursing professionals also showed that nursing care at CAPS needs to follow the psychosocial model and presented positive characteristics from this team, which seeks to provide a qualified work aimed at the user's singularity, the reception, qualified listening, and the interdisciplinarity.

It was noticed that there is still in the mental health field, specifically among the nursing team, stigma, fear, anguish, and 
professional dissatisfaction. This scenario is worrying, making us reflect on the need for reformulations in the work processes because the permanence of the current situation has been wearing those professionals, day after day.

Given the above, nursing professionals are invited daily to think over their practice, seeking continuous assistance and working conditions. Therefore, understanding that issues of difficult resolution accompany the performance of the nursing team at CAPS is the first step to minimize the anguish of this professional group, who understands and takes responsibility for their role in the process of psychosocial rehabilitation of people in psychological pain, despite the setbacks that arise in the reality of each service.

\section{REFERENCES}

1. Amarante P. Saúde Mental e Atenção Psicossocial. Editora Fiocruz: Rio de Janeiro, 2017. 123 p.

2. Pitta AMF, Guljor AP. The violence of the counter-psychiatric reform in Brazil: on attack on democracy in times of struggle for Humans Rights and Social Justice. Cad CEAS. 2019;246:6-14. https://doi.org/10.25247/2447-861X.2019.n246.p6-14

3. Ministério da Saúde (BR). Portaria n 3.088, de 23 de dezembro de 2011. Institui a Rede de Atenção Psicossocial para pessoas com sofrimento ou transtorno mental e com necessidades decorrentes do uso de crack, álcool e outras drogas, no âmbito do Sistema Único de Saúde (SUS) [Internet]. Diário Oficial da União 2013[cited 2020 Apr 28];Seção 1. Available from: https://www.saude.gov.br/images/sismob2/ pdf/saudemental/Portaria\%203088_2011_republicada.pdf

4. Ministério da Saúde (BR). Portaria GM/MS n 336, de 19 de fevereiro de 2002. Estabelece que os Centros de Atenção Psicossocial poderão constituir-se nas seguintes modalidades de serviços: CAPS I, CAPS II e CAPS III, definidos por ordem crescente de porte/complexidade e abrangência populacional [Internet]. Diário Oficial da União 2002[cited 2020 Apr 28];Seção 1. Available from: http://www.saude.mg.gov.br/ images/documentos/Portaria_336.pdf

5. Baptista JA, Camatta MW, Filippon PG, Schneider JF. Singular therapeutic project in mental health: an integrative review. Rev Bras Enferm. 2020;73(2):e20180508. https://doi.org/10.1590/0034-7167-2018-0508

6. Kolhs M, Olschowsky A, Ferraz L. Suffering and defense in work in a mental health care service. Rev Bras Enferm. 2019;72(4):903-9. https:// doi.org/10.1590/0034-7167-2018-0140

7. Silva TCS, Santos TM, Campelo IGMT, Cardoso MMVN, Silva AD, Peres MAA. Night Admission at a Psychosocial Care Center III. Rev Bras Enferm. 2020;73(1):e20170964. https://doi.org/10.1590/0034-7167-2017-0964

8. Nóbrega MPSS, Silva GBF, Sena ACR. A reabilitação psicossocial na rede oeste do município de São Paulo: potencialidades e desafios. Rev Gaúcha Enferm. 2018;39:e2017-0231. https://doi.org/10.1590/1983-1447.2018.2017-0231

9. Camilo SO. Considerações sobre a estrutura de uma Pesquisa Qualitativa - como ler e como planejar um estudo qualitativo. ABCS Health Sci. 2018[cited 2020 Apr 28];43(2):67-68. Available from: https://www.portalnepas.org.br/abcshs/article/download/1187/804

10. Coimbra MNCT, Martins AMO. Estudo de caso como abordagem metodológica no ensino superior. Nuances [Internet]. 2013 [cited 2020 Sep 16];24(3):31-46. https://doi.org/10.14572/nuances.v24i3.2696

11. Bardin L. Análise de conteúdo. São Paulo: Edições 70. 2016.

12. Garcia APRF, Freitas MIP, Lamas JLT, Toledo VP. Nursing process in mental health: an integrative literature review. Rev Bras Enferm. 2017;70(1):209-18. https://doi.org/10.1590/0034-7167-2016-0031

13. Almeida PA, Mazzaia MC. Nursing Appointment in Mental Health: experience of nurses of the network. Rev Bras Enferm. 2018;71(Suppl 5):2154-60. https://doi.org/10.1590/0034-7167-2017-0678

14. Alves SR, Santos RP, Yamaguchi UM. Satisfaction of the nursing team in mental health services: a comparative study between public and private institution professionals. Rev Min Enferm. 2017;21:e-993. https://doi.org/10.5935/1415-2762.20170003

15. Rocha EM, Lucena AF. Single Therapeutic Project and Nursing Process from an interdisciplinary care perspective. Rev Gaúcha Enferm. 2018;39:e2017-0057. https://doi.org/10.1590/1983-1447.2018.2017-0057

16. Silva JVS, Brandão TM. Professional profile of the nurses of the Centers of Psychosocial Attention of a capital of the Northeast, Brazil. Rev Enferm UFJF. 2019;5(1):1-12. https://doi.org/10.34019/2446-5739.2019.v5.16942

17. Tavares CMM. Permanent education of the team of nursing for the care in the services of mental health. Texto Contexto Enferm. 2006;15(2):287-95. https://doi.org/10.1590/S0104-07072006000200013

18. Barros S, Nóbrega MPSS, Santos JC, Fonseca LM, Floriano LSM. Mental health in primary health care: health-disease according to health professionals. Rev Bras Enferm. 2019;72(6):1687-95. https://doi.org/doi.org/10.1590/0034-7167-2018-0743

19. Vieira GLC. Physical aggression against nursing technicians in psychiatric hospitals. Rev Bras Saude Ocup. 2017;42:e8. https://doi. org/10.1590/2317-6369000004216

20. Monteiro C, Passos J. Violence and health professionals at the psychiatric hospital. RPESM. 2019;21:54-61. https://doi.org/10.19131/ rpesm. 0238

21. Mesquita AC, Carvalho EC. Therapeutic listening as a health intervention strategy: an integrative review. Rev Esc Enferm USP. 2014;48(6):1127-36. https://doi.org/10.1590/S0080-623420140000700022 
22. Nascimento JMF, Carvalho Neto FJ, Vieira Jr DN, Braz ZR, Costa Jr IG, Ferreira ACC, et al. Therapeutic listening: a technology of mental health care. Rev Enferm UFPE [Internet]. 2020 [cited 2020 Apr 20];14:e244257. Available from: https://periodicos.ufpe.br/revistas/ revistaenfermagem/article/view/244257

23. Sousa KHJF, Gonçalves TS, Silva MB, Soares ECF, Nogueira MLF, Zeitoune RCG. Risks of illness in the work of the nursing team in a psychiatric hospital. Rev Latino-Am Enfermagem. 2018;26:e3032. https://doi.org/10.1590/1518-8345.2458.3032

24. Oliveira CA, Oliveira DCP, Cardoso EM, Aragão ES, Bittencourt MN. Moral distress of nursing professionals of a psychosocial care center. Cienc Saude Colet. 2020;25(1):191-8. https://doi.org/10.1590/1413-81232020251.29132019

25. Silva NS, Esperidião E, Cavalcante ACG, Souza ACS, Silva KKC. Development of human resources for work in mental health services. Texto Contexto Enferm. 2013 Dec;22(4):1142-51. https://doi.org/10.1590/s0104-07072013000400033

26. Rodrigues J, Lazzari DD, Martini JG, Testoni AK. Professors' perception of mental health teaching in nursing. Texto Contexto Enferm. 2019;28:e20170012. https://doi.org/10.1590/1980-265X-TCE-2017-0012

27. Vargas D, Maciel MED, Bittencourt MN, Lenate JS, Pereira CFO. Teaching psychiatric and mental health nursing in brazil: curricular analysis of the undergraduation course. Texto Contexto Enferm. 2018;27(2):e2610016. https://doi.org/10.1590/0104-070720180002610016

28. Prudencio JDL, Senna MCM. Setbacks in Care for users of alcohol and other drugs. Argumentum. 2018;10(3):79-93. https://doi.org/doi. org/10.18315/argumentum.v10i3.20854

29. Silva EA. O trabalho em equipe na saúde mental: construções rizomáticas e (re) invenções. Rev Nufen: Phenom Interd. 2019;11(2):01-18. Available from: http://pepsic.bvsalud.org/pdf/rnufen/v11n2/a02.pdf 